\title{
Micronucleus Test Using Cultured New Born Rat Astrocytes
}

\author{
Yuichi MIYAKOSHI*, Yuji SUZUKI, Motoi OOIDA, \\ Akira TAKAHASHI and Mitsuhiro TSUKUI
}

\begin{abstract}
Department of Public Health and Environmental Medicine, The Jikei University School of Medicine, 3-25-8, Nishishinbashi, Minato-ku, Tokyo 105-8461, Japan
\end{abstract}

Received October 30, 1998 and accepted November 27, 1998

\begin{abstract}
Micronuclei is induced in cytoplasm as a consequence of the formation of chromosomal fragments or remaining chromosomes during cell division by the cause of clastogens or spindle poisons, and is used as an indicator of genotoxicity screening tests. There are few short-term genotoxicity screening tests using brain cells. We attempted to establish a new in vitro micronucleus test (MN test) system by use of central nervous system cells. Primary cultured astrocytes were prepared from newborn male Sprague-Dawley (SD) rats. In growth curve of astrocytes, doubling time was determined to be $31 \mathrm{~h}$. In time study, the highest frequency of micronuclei was observed at $48 \mathrm{~h}, 72 \mathrm{~h}$ and $6 \mathrm{~h}$-exposure-66 h-recovery by vincristine (VCR), mitomycin C (MMC) without metabolic activation system and cyclophosphamide (CPM) with metabolic activation system, respectively. Dose-response relationships between micronucleus frequency and concentrations of MMC, VCR and CPM were observed, respectively. It is suggested that the in vitro MN test using new born rat-astrocytes could be used as a screening test of environmental and occupational genotoxic chemicals in the central nervous system cells.
\end{abstract}

Key word: Micronuclei, Rat-astrocyte, Mitomycin C, Vincristine, Cyclophosphamide

\section{Introduction}

We are exposed to environmental and occupational hazardous chemicals in daily life. The carcinogenicity assay with experimental animals have been used to estimate the carcinogenic potential of chemicals ${ }^{1)}$. But it costs much expense, and it takes a few years. Since recent progress in cancer and mutation research has proven a high correlation between mutagenicity and carcinogenicity, mutagenicity testing on chemicals has become more significant in evaluating their carcinogenicity ${ }^{2)}$. Therefore many low cost and short-term genotoxicity screening tests such as the Ames Salmonella mutagenicity assay, chromosomal aberration test and in vivo micronucleus test (MN test), are widely used to detect mutagenicity of chemicals predicting of carcinogens ${ }^{3)}$.
Both epidemiological studies and carcinogenicity tests in Sprague-Dawley (SD) rats suggested that some of environmental and occupational hazardous chemicals induced not only brain tumors but also genotoxic potential ${ }^{4-6)}$. As brain tumors usually arise from glial cells or meningeal cells ${ }^{7}$, it may be useful to establish a genotoxic assay system using cultured astrocytes in order to prevent brain tumors and to study the mechanism of generation of brain tumors.

Micronuclei is induced in cytoplasm as a consequence of the formation of chromosomal fragments or remaining chromosomes during cell division by the cause of clastogens or spindle poisons, and is used as an indicator of genotoxicity screening methods ${ }^{8)}$. The aim of this experiment is to establish an in vitro $\mathrm{MN}$ test using new born rat cultured astrocytes.

\footnotetext{
*To whom correspondence should be addressed.
} 


\section{Materials and Methods}

\section{Experimental animals}

Four-five day-old male SD rats used to prepare primary cultured astrocytes and seven-week-old male SD rats used to prepare $9,000 \mathrm{~g}$ supernatant (S9) were obtained from Charles River Japan Inc. Rats were kept in a clean animal room (constant temperature $24-25^{\circ} \mathrm{C}$, humidity $45-55 \%$, lights on 8 a.m. to 8 p.m.). The rats were given chow (FR2, Funabashi Farm Co., Ltd., Japan) and tap water ad libitum. All animal experiments were performed in accordance with Animal Experiments Guidelines of the Jikei University School of Medicine.

\section{Chemicals}

Dulbecco's phosphate-buffered saline (PBS), minimum essential medium with Earle's salts (MEM), penicillinstreptomycin, HEPES buffer solution, and fetal bovine serum (FBS) were obtained from GIBCO BRL, Life Technologies, Inc., Rockville, Md., USA. DNase I, trypsin solution, trypsin/ EDTA solution, NADP, and poly-D-lysine were obtained from Boehringer Manheim GmbH, Germany. Rabbit polyclonal anti-cow glial fibrillary acidic protein (GFAP) antibody, and rhodamine-conjugated swine polyclonal antirabbit immunogloblin were obtained from DAKO A/S, Denmark. Acridine orange, and glucose-6-phosphate were purchased from Sigma, St. Louis, Mo., USA. Phenobarbital sodium, and $\beta$-naphthoflavone were purchased from Wako Pure Chemical Industries. Ltd., Japan. Mitomycin C (MMC) was obtained from Kyowa Hakko Kogyo Co., Ltd., Japan. Vincristine (VCR) sulfate was obtained from Eli Lilly Japan K. K. Cyclophosphamide (CPM) was obtained from Shionogi and Co., Ltd., Japan.

\section{Preparation of primary cultured astrocytes}

The whole brains were prepared from four-five day-old SD rats according to the method of McCarthy et al. ${ }^{9}$, and were incubated in PBS containing $0.25 \%$ trypsin, $40 \mu \mathrm{g} / \mathrm{ml}$ DNase for $30 \mathrm{~min}$ at $37^{\circ} \mathrm{C}$. After inactivation of trypsin activity, the cell suspensions were centrifuged at $1000 \mathrm{rpm}$ for $5 \mathrm{~min}$. The cell pellet was resuspended in MEM containing $5 \% \mathrm{FBS}, 5 \mathrm{mg} / \mathrm{ml}$ glucose, $100 \mathrm{U} / \mathrm{ml}$ penicillin, and $100 \mu \mathrm{g} / \mathrm{ml}$ streptomycin. The suspended brain cells were dissociated into single cells by gently pipetting. The cell suspension was divided into $75 \mathrm{~cm}^{2}$-culture flasks (Falcon). Then they were incubated in a $5 \% \mathrm{CO}_{2} / 95 \%$ air incubator at $37^{\circ} \mathrm{C}$. Two-three days after, the culture flasks were shaken on an orbital shaker (Bel-Art products, USA) for about 12 hours at $37^{\circ} \mathrm{C}$ to separate astrocytes from mixed glial cells, neurons, fibroblasts and other cells ${ }^{9}$. After 3-4 wk, cultured cells were used for the doubling-time study, for the cell growth inhibition test, and for the micronucleus assay.

\section{Preparation of $S 9$}

S9 for metabolic activation was prepared from the livers of male SD rats treated with sodium phenobarbital and 5,6Benzoflavone as enzyme inducers ${ }^{10}$. The ingredients of S9mix and the final concentration of S9 in mediumin (5\%) of in vitro micronuclei assay ${ }^{5)}$, similarly applied to this study. S9mix was filtered through $0.22-\mu \mathrm{m}$ pore size cellulose acetate membranes before usage.

\section{Staining of astrocytes}

The cells growing on the coverslips were rinsed in PBS, and then were fixed with cold methanol for $10 \mathrm{~min}$. The fixed cells were washed in PBS containing $0.1 \%$ triton X100 , and then incubated with rabbit polyclonal anti cow GFAP antibody $(1: 100)$ for $60 \mathrm{~min}$ at $37^{\circ} \mathrm{C}$. Then cells were washed in PBS, and were incubated with rhodamine-conjugated swine polyclonal anti-rabbit immunogloblin for $30 \mathrm{~min}$ at room temperature. To recognize main nuclei and micronuclei, the cells were stained with $1.25 \mathrm{mM}$ acridine orange in distilled water for $5 \mathrm{~min}$ at room temperature. After the cells were washed in PBS, coverslips were mounted on glass slides in PBS. Observations of astrocytes were made under an Olympus microscope equipped with phase contrast, fluorescein, and rhodamine optics at 300x magnification. Astrocytes were identified as GFAP-positive nucleated cells. The ratios of astrocytes were determined by counting 1000 nucleated cells.

\section{Calculation of the cell numbers}

The nucleated cells plated on 6-well-plate (Falcon) with MEM containing $15 \% \mathrm{FBS}$, and $5 \mathrm{mg} / \mathrm{ml}$ glucose (15\% FBS/ MEM) in growth inhibition ratio study were washed several times with physiological saline, and then fixed in $10 \%$ formalin neutral buffer solution for $10 \mathrm{~min}$ at room temperature. The fixed cells were washed with distilled water, and stained with $0.1 \%$ crystal violet in distilled water for $10 \mathrm{~min}$ at room temperature. Using a Monocellator (Olympus, Japan) at the absorbance of $555 \mathrm{~nm}$, the growth inhibition ratio was calculated from the intensity of solventtreated cells as $100 \%$ and intensity without cells as $0 \%$. Then the cell growth inhibition ratio for triplicated wells was estimated. 
The concentration of $50 \%$ growth inhibition ratio was calculated from the linear function found two values before and behind $50 \%$ growth inhibition ratio.

\section{Determination of doubling time}

To estimate the induction of micronuclei in astrocyte in logarithmic growth phase, doubling time was determined. In growth curve, culture time was plotted at the $\mathrm{X}$ axis, and cell numbers was plotted at the $\mathrm{Y}$ axis in logarithmic scale. In logarithmic growth phase, the numerical formula of regression was expressed by the relationship between cell plating time and cell numbers. The doubling time of nucleated cells was determined from this formula.

\section{Micronucleus assay}

Ten thousand nucleated cells suspended with $15 \%$ FBS/ MEM were plated on poly-D-lysine coated plastic 30-mm rounded coverslips in 6-well-plate. The culture plates were incubated in a $5 \% \mathrm{CO}_{2}$ incubator at $37^{\circ} \mathrm{C}$.

The nucleated cells were rinsed with PBS. And the cells on the coverslips fixed with cold methanol were stained with GFAP and acridine orange. The frequency of micronucleated astrocytes was determined by counting 1000 GFAP-positive nucleated cells.

The identification of micronucleated cells used the following criteria; counted cells should have normal cell morphology with cytoplasmic borders, the diameter of the micronuclei should be no larger than one-third of the main nucleus, and bi- or polynucleated cells should be not scored ${ }^{6}$.

Triplicated coverslips were assayed for each time and dose. The experimental results were analyzed statistically using the Kastenbaum-Bowman table ${ }^{11)}$.

\section{Results}

\section{Growth curve}

The cells cultured in $75 \mathrm{~cm}^{2}$-culture flasks were washed several times with PBS, and then treated with $0.25 \%$ trypsin and $0.02 \%$ EDTA in PBS for $20 \mathrm{~min}$ at $37^{\circ} \mathrm{C}$. After inactivation of trypsin activity, the cell suspensions were centrifuged at $1000 \mathrm{rpm}$ for $5 \mathrm{~min}$. The cell pellet was resuspended in $15 \%$ FBS/MEM. The nucleated cell density was adjusted to $5 \times 10^{5}$ cells/dish using a hemocytometer with $0.2 \%$ trypan blue staining, and the cells were plated on $60-\mathrm{mm}$ petri dishes with $15 \% \mathrm{FBS} / \mathrm{MEM}$. The nucleated cell density of dishes were counted after $24,48,72,96,120$, 144 , and $168 \mathrm{~h}$ after cells plating. Triplicated dishes were counted at each time. The ratio of GFAP-positive cells in nucleated cells was determined at 168 hours after plating.

The number of nucleated cells was decreased at $24 \mathrm{~h}$ after plating, and increased until $72 \mathrm{~h}$ in logarithmic growth phase (Fig. 1). The cell number reached a plateau $\left(1 \times 10^{6}\right.$ cells/ dish) after $96 \mathrm{~h}$. The relationship between cell plating time (from $24 \mathrm{~h}$ to $72 \mathrm{~h}$ ) and cell numbers was determined by the following formula:

$$
\mathrm{X}=102.5 \times \log (\mathrm{Y})-536.7
$$

$\mathrm{X}$ : culture time (h), Y: cell numbers/plate.

Consequently, doubling time of nucleated cells was determined to be $31 \mathrm{~h}$.

The ratio of GFAP-positive cells (astrocytes) in nucleated cells at $168 \mathrm{~h}$ after cell plating was $93.0 \pm 2.0 \%$.

\section{Growth inhibition ratio}

The one hundred thousand of the nucleated cells were plated on 6-well-plate (Falcon) with 15\% FBS/MEM for $48 \mathrm{~h}$, and the culture plates were exposed to MMC, VCR without metabolic activation system, and CPM with metabolic activation system in a $5 \% \mathrm{CO}_{2}$ incubator at $37^{\circ} \mathrm{C}$. The exposure time of chemicals in growth inhibition ratio study was chosen to above twice of the doubling time, $72 \mathrm{~h}$.

The concentrations of MMC exposed for $72 \mathrm{~h}$ were $8 \times$ $10^{-5}, 1.6 \times 10^{-4}, 3.2 \times 10^{-4}, 6.4 \times 10^{-4}$, and $1.28 \times 10^{-3} \mathrm{mM}$, and VCR were $8.5 \times 10^{-6}, 1.7 \times 10^{-5}, 3.4 \times 10^{-5}, 6.8 \times 10^{-5}$, and $1.35 \times 10^{-4} \mathrm{mM}$. The $50 \%$ growth inhibition ratio of MMC was calculated to $5.7 \times 10^{-4} \mathrm{mM}$ (Fig. 2). And the $50 \%$ growth inhibition ratio of VCR was calculated to $3.2 \times$

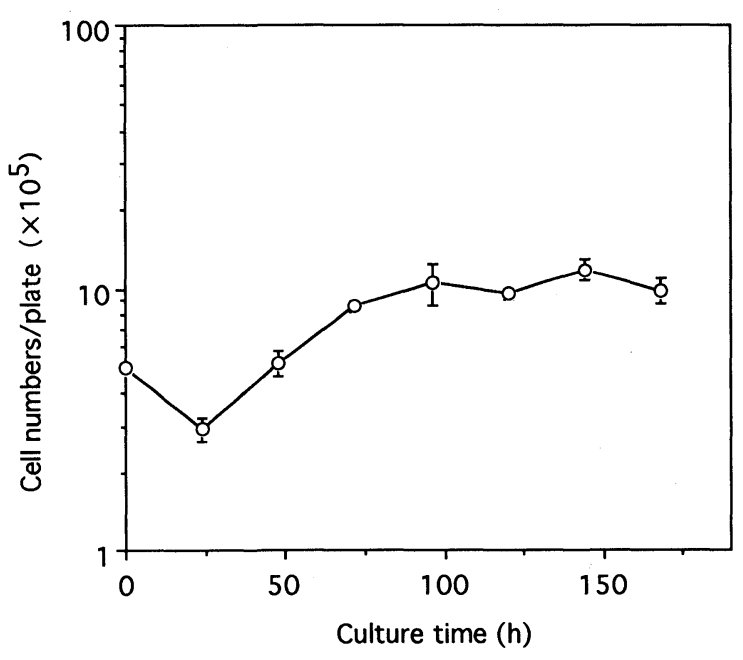

Fig. 1. Growth curve of cultured nucleated cells prepared from new born rat brain.

Triplicated dishes were counted at each points, and standard deviation per points was shown. 


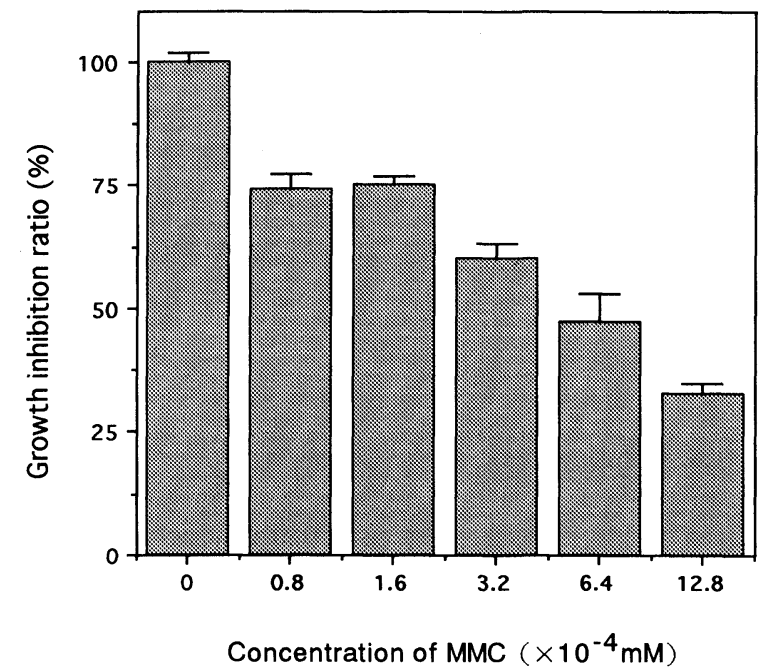

Fig. 2. Growth in cultured nucleated cells prepared from new born rat brain inhibited by $72 \mathrm{~h}$ exposure of MMC.

Triplicated plates were counted at each points, and standard deviation per points was shown.

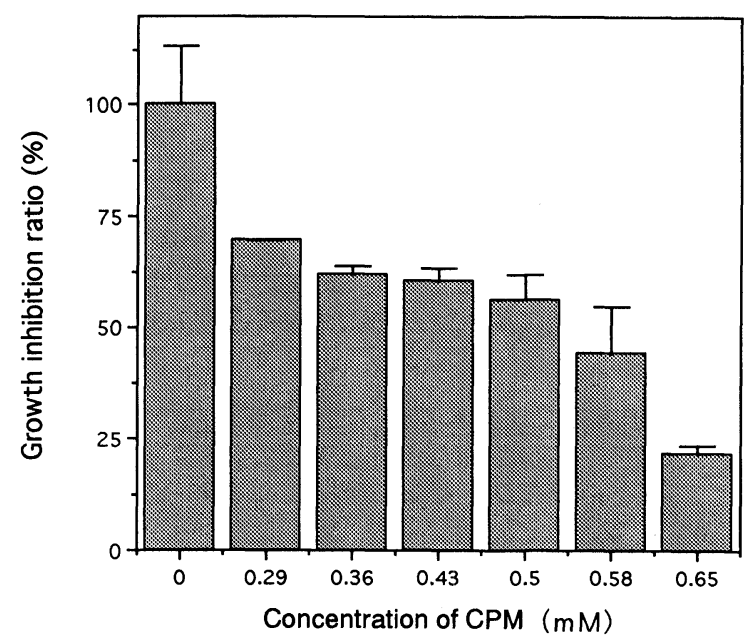

Fig. 4. Growth in cultured nucleated cells prepared from new born rat brain inhibited by 6 h-exposure time of CPM with metabolic activation system and $66 \mathrm{~h}$-recovery time.

Triplicated plates were counted at each points, and standard deviation per points was shown.

$10^{-5} \mathrm{mM}$ (Fig. 3).

The nucleated cells exposed to CPM with 5\% S9mix for $6 \mathrm{~h}$ (exposure time) $)^{5}$, were exchanged to fresh $15 \% \mathrm{FBS} /$ MEM, and cultured in 15\% FBS/MEM for $66 \mathrm{~h}$ (recovery time). The concentrations of CPM were $0.14,0.22,0.29$, $0.36,0.43,0.50,0.58$ and $0.65 \mathrm{mM}$. Physiological saline was used as a solvent control for the three chemicals. The

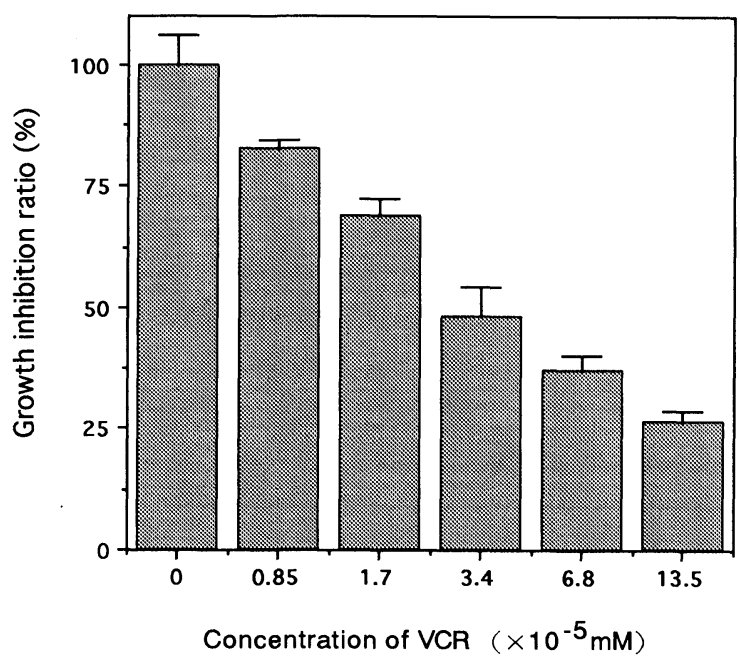

Fig. 3. Growth in cultured nucleated cells prepared from new born rat brain inhibited by $72 \mathrm{~h}$ exposure of VCR.

Triplicated plates were counted at each points, and standard deviation per points was shown.

Table 1. Frequency of micronuclei in cultured new born rat astrocytes induced by $3.2 \times 10^{-4} \mathrm{mM}$ MMC in time study

\begin{tabular}{ccc}
\hline \multirow{2}{*}{$\begin{array}{c}\text { Exposure time } \\
(\mathrm{h})\end{array}$} & \multicolumn{2}{c}{ Frequency of micronuclei } \\
\cline { 2 - 3 } & Control (\%॰ $\pm \mathrm{SD})$ & MMC (\%॰ $\pm \mathrm{SD})$ \\
\hline 24 & $8.0 \pm 0.00$ & $15.3 \pm 0.58^{*}$ \\
48 & $6.3 \pm 1.53$ & $18.7 \pm 3.51^{* *}$ \\
72 & $8.0 \pm 1.73$ & $32.7 \pm 8.50^{* *}$ \\
96 & $6.7 \pm 2.08$ & $23.0 \pm 2.65^{* *}$ \\
120 & $6.7 \pm 2.08$ & $17.0 \pm 2.00^{* *}$ \\
\hline
\end{tabular}

$*: \mathrm{p}<0.05 .{ }^{* *}: \mathrm{p}<0.01$. MMC: mitomycin $\mathrm{C}, \mathrm{SD}:$ standard deviation.

$50 \%$ growth inhibition ratio of CPM was calculated to 0.54 mM (Fig. 4).

\section{Frequency of micronuclei induced by MMC}

Time study was performed at the concentrations of $3.2 \times$ $10^{-4} \mathrm{mM}$ MMC for $24,48,72,96$, and $120 \mathrm{~h}$. Significant increased frequencies of micronuclei compared with control were observed at $24 \mathrm{~h}(\mathrm{p}<0.05), 48,72,96$, and $120 \mathrm{~h}$ $(\mathrm{p}<0.01)$. The highest frequency of micronuclei was obtained at $72 \mathrm{~h}$ (Table 1). Dose-response study of MMC was done at $72 \mathrm{~h}$ exposure of MMC. The concentrations of MMC were shown on Table 2. From dose-response study at $72 \mathrm{~h}$ exposure time, significant increased frequencies of 
Table 2. Frequency of micronuclei in cultured new born rat astrocytes induced by MMC at $72 \mathrm{~h}$ exposure in dose-response study

\begin{tabular}{cc}
\hline $\begin{array}{c}\text { Concentration of MMC } \\
\left(\times 10^{-4} \mathrm{mM}\right)\end{array}$ & $\begin{array}{c}\text { Frequency of micronuclei } \\
(\% \circ \pm \mathrm{SD})\end{array}$ \\
\hline 0.0 & $8.7 \pm 0.58$ \\
0.8 & $14.3 \pm 4.16^{*}$ \\
1.6 & $14.7 \pm 1.53^{*}$ \\
3.2 & $17.3 \pm 2.52^{* *}$ \\
6.4 & $26.7 \pm 4.93^{* *}$ \\
12.8 & $10.7 \pm 2.08$
\end{tabular}

*: $\mathrm{p}<0.05 . * *: \mathrm{p}<0.01$. MMC: mitomycin C, SD: standard deviation.
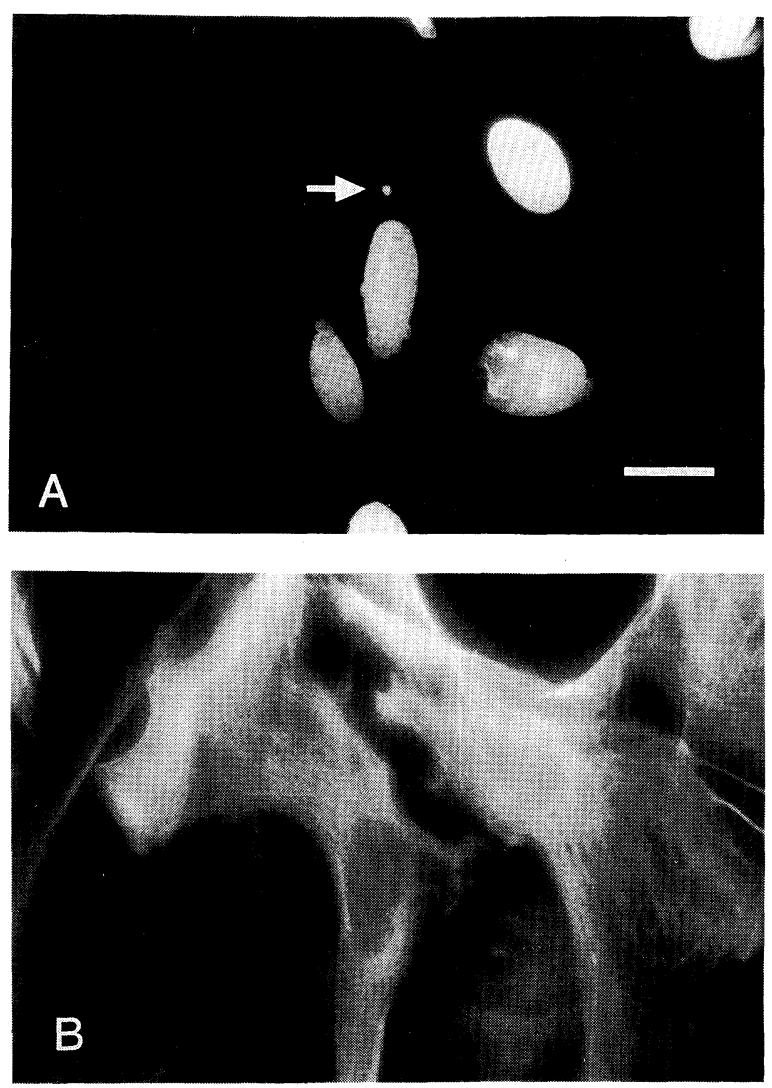

Fig. 5. Micronuclei induced by $1.6 \times 10^{-4} \mathrm{mM} M M C$ in astrocytes at $72 \mathrm{~h}$ exposure.

Nucleated cells were double labeled with acridine orange to identify main nuclei and micronuclei (A), and with GFAP antibody to identify astrocytes (B). Arrowhead indicates micronuclei. Scale bar $=20 \mu \mathrm{m}$.

micronuclei were observed at all doses except the highest concentration of $12.8 \times 10^{-4} \mathrm{mM}$ (Table 2). The doseresponse relationship of micronucleus frequencies was
Table 3. Frequency of micronuclei in cultured new born rat astrocytes induced by $3.4 \times 10^{-5} \mathrm{mM}$ VCR in time study

\begin{tabular}{ccc}
\hline \multirow{2}{*}{$\begin{array}{c}\text { Exposure time } \\
\text { (h) }\end{array}$} & \multicolumn{2}{c}{ Frequency of micronuclei } \\
\cline { 2 - 3 } & Control (\%o \pm SD) & VCR (\%o \pm SD) \\
\hline 24 & $6.7 \pm 0.58$ & $11.3 \pm 1.15$ \\
48 & $8.0 \pm 1.00$ & $22.3 \pm 2.08^{* *}$ \\
72 & $8.3 \pm 2.52$ & $21.3 \pm 1.53^{* *}$ \\
96 & $7.3 \pm 2.52$ & $18.3 \pm 2.52^{* *}$ \\
120 & $6.7 \pm 1.15$ & $17.0 \pm 1.00^{* *}$ \\
\hline
\end{tabular}

**: $\mathrm{p}<0.01$. VCR: vincristine, SD: standard deviation.

Table 4. Frequency of micronuclei in cultured new born rat astrocytes induced by VCR at $48 \mathrm{~h}$ exposure in dose-response study

\begin{tabular}{cc}
\hline $\begin{array}{c}\text { Concentration of VCR } \\
\left(\times 10^{-5} \mathrm{mM}\right)\end{array}$ & $\begin{array}{c}\text { Frequency of micronuclei } \\
(\% \circ \pm \mathrm{SD})\end{array}$ \\
\hline 0.0 & $7.3 \pm 1.53$ \\
0.85 & $13.7 \pm 1.15^{*}$ \\
1.7 & $15.3 \pm 3.51^{* *}$ \\
3.4 & $23.0 \pm 5.57^{* *}$ \\
6.8 & $21.0 \pm 1.00^{* *}$ \\
13.5 & $20.3 \pm 0.58^{* *}$ \\
\hline
\end{tabular}

$*: \mathrm{p}<0.05 . * *: \mathrm{p}<0.01$. VCR: vincristine, SD: standard deviation.

observed until $6.4 \times 10^{-4} \mathrm{mM}$ MMC. Frequencies of micronuclei were decreased at $12.8 \times 10^{-4} \mathrm{mM}$ (Table 2). Fig. $5 \mathrm{~A}$ and $\mathrm{B}$ show the morphological features of micronuclei in astrocytes following $72 \mathrm{~h}$ exposure to MMC at $1.6 \times 10^{-4}$ $\mathrm{mM}$.

\section{Frequency of micronuclei induced by VCR}

Time study was performed at the concentrations of $3.4 \times$ $10^{-5} \mathrm{mM}$ VCR for $24,48,72,96$, and $120 \mathrm{~h}$. Significant increased frequencies of micronuclei in time study were observed at 48, 72, 96, and $120 \mathrm{~h}(\mathrm{p}<0.01)$. The highest frequency of micronuclei was obtained at $48 \mathrm{~h}$ (Table 3 ). Dose-response study of VCR was done at $48 \mathrm{~h}$ exposure of VCR. The concentrations of VCR were shown on Table 4. Table 4 shows a significant increase of micronucleus frequency at $48 \mathrm{~h}$ exposure in dose-response study at $8.5 \times$ $10^{-6}(\mathrm{p}<0.05), 1.7 \times 10^{-5}, 3.4 \times 10^{-5}, 6.8 \times 10^{-5}$, and $13.5 \times$ $10^{-5} \mathrm{mM}(\mathrm{p}<0.01)$. The dose-response of micronucleus frequencies was observed up to $3.4 \times 10^{-5} \mathrm{mM}$ and then decreased tendency to $13.5 \times 10^{-5} \mathrm{mM}$. 
Table 5. Frequency of micronuclei in cultured new born rat astrocytes induced by $0.50 \mathrm{mM} \mathrm{CPM}$ with metabolic activation system in time study

\begin{tabular}{ccc}
\hline \multirow{2}{*}{$\begin{array}{c}\text { Exposure time- recovery time } \\
\text { (h) }\end{array}$} & \multicolumn{2}{c}{ Frequency of micronuclei } \\
\cline { 2 - 3 } & Control (\%० \pm SD) & CPM (\%० \pm SD) \\
\hline $6-18$ & $7.3 \pm 1.53$ & $13.0 \pm 6.25^{* *}$ \\
$6-42$ & $8.0 \pm 1.73$ & $16.7 \pm 4.16^{* *}$ \\
$6-66$ & $7.7 \pm 1.53$ & $20.0 \pm 1.73^{* *}$ \\
$6-90$ & $6.0 \pm 2.00$ & $13.7 \pm 4.62^{* *}$ \\
$6-114$ & $6.3 \pm 1.53$ & $9.0 \pm 3.00$ \\
\hline
\end{tabular}

**: p<0.01. CPM: cyclophosphamide, SD: standard deviation.

\section{Frequency of micronuclei induced by CPM}

In time study of $0.50 \mathrm{mM} \mathrm{CPM}$ with S9mix, the cells were exposed for $6 \mathrm{~h}$ (exposure time) and cells were cultured in fresh 15\% FBS/MEM for an additional 18, 42, 66, 90, and $114 \mathrm{~h}$ (recovery time). Significant increases of micronucleus frequency in time study of $0.50 \mathrm{mM}$ were observed at 6-18, 6-42, 6-66, and 6-90 h $(\mathrm{p}<0.01)$. The highest frequency of micronuclei was obtained at 6-66 h (Table 5). Dose-response study of CPM at the concentrations of $0.036,0.072,0.18,0.40$, and $0.50 \mathrm{mM}$ was carried out in $6 \mathrm{~h}$-exposure- $66 \mathrm{~h}$-recovery $(6-66 \mathrm{~h})$. The frequencies of micronuclei obtained from a dose-response study in 6-66 h increased significantly at $0.036,0.072,0.18,0.40$, and 0.50 $\mathrm{mM}(\mathrm{p}<0.01)$ (Table 6). The dose-response relationship was observed to concentrations until $0.18 \mathrm{mM}$ of CPM and then decreased to $0.50 \mathrm{mM}$ (Table 6).

\section{Discussion}

Since a highly significant correlation has been reported between mutagenicity and carcinogenicity, genotoxicity screening for chemicals has been increasingly important for evaluating their carcinogenicity ${ }^{2}$. There are some genotoxicity screening tests, such as in vitro $\mathrm{MN}$ test using organs and tissue-derived cells, which take from one wk to six months to estimate the genotoxicity of chemicals ${ }^{3,12}$. The in vitro SD rat-astrocyte MN test developed by us would be important as a short-term screening test because: (1) it takes about six wk to estimate the genotoxicity of chemicals; (2) brain tumors usually arise from glial cells ${ }^{7)}$ and there are few genotoxicity tests using brain-derived cells $s^{6}$; (3) SD rat-astrocyte might be sensitive to detect genotoxic chemicals since Maekawa et al. reported that the incidence of spontaneous astrocytomas in SD rats were higher than in other several strains of rat $^{13}$.
Table 6. Frequency of micronuclei in cultured new born rat astrocytes induced by CPM at $6 \mathrm{~h}$-exposure$66 \mathrm{~h}$-recovery in dose-response study

\begin{tabular}{cc}
\hline $\begin{array}{c}\text { Concentration of CPM } \\
(\mathrm{mM})\end{array}$ & $\begin{array}{c}\text { Frequency of micronuclei } \\
(\% \circ \pm \mathrm{SD})\end{array}$ \\
\hline 0.0 & $7.0 \pm 2.00$ \\
0.036 & $25.0 \pm 1.00^{* *}$ \\
0.072 & $29.3 \pm 5.13^{* *}$ \\
0.18 & $71.0 \pm 8.72^{* *}$ \\
0.29 & $30.0 \pm 5.57^{* *}$ \\
0.40 & $18.3 \pm 3.21^{* *}$ \\
0.50 & $17.3 \pm 2.08^{* *}$ \\
\hline
\end{tabular}

**: $\mathrm{p}<0.01$. CPM: cyclophosphamide, SD: standard deviation.

We applied three anticancer agents (MMC, VCR and CPM) as mutagens, which have been known to produce micronuclei in a variety of cultured cells ${ }^{5,14)}$, to establish the in vitro ratastrocyte MN test. The anticancer action of MMC reported caused severe fragmentation, depolymerization, irreversible cross-linking of DNA in the cells, and inhibition of cellular DNA synthesis ${ }^{15}$. The anticancer action of VCR reported would be due to the inhibition of formation and to the disruption of mitotic spindle microtubules ${ }^{16}$. The anticancer action of CPM reported was activated by hepatic mixed functions oxidases and the metabolites indicate anticancer effects. CPM is oxidized by P450 contained in S9, and is metabolized to phosphoramide mustard, nornitrogen mustard, and acrolein. These three metabolites of CPM bind to DNA and form DNA adducts ${ }^{14}$. In time study, the highest frequency of micronuclei was observed at $48 \mathrm{~h}, 72 \mathrm{~h}$ by VCR and MMC without S9mix, and $6 \mathrm{~h}$-exposure-66 hrecovery by CPM with $\mathrm{S} 9 \mathrm{mix}$, respectively. The doubling time of rat-astrocyte was determined to be $31 \mathrm{~h}$. It was suggested that clastogenic chemicals such as MMC, CPM induced structural chromosomal aberrations in the first cell cycle and then the micronuclei was directly derived from them in the second cell cycle ${ }^{16)}$. It was also suggested that spindle poison such as VCR induced micronuclei, which was caused by lagging of a whole chromosomes in the first cell cycle. And we have shown that micronucleus induction in rat-astrocyte is dose-dependent for these three genotoxic agents. Micronuleus frequency of astrocytes was decreased at higher concentrations for three chemicals, since it was suggested that micronuceus frequency was decreased as the cytotoxicity induced by chemicals was observed ${ }^{55}$.

Our study has shown that micronuclei was induced by 
use of both methods without S9mix (MMC, VCR) and with S9mix (CPM). It is suggested that this MN test using new born rats-astrocyte could be used as a screening test in the same manner as the Ames Salmonella mutagenicity assay, in vitro micronuclei assay using established cell lines and cultured human lymphocytes ${ }^{5,12)}$. The astrocytomas induced by chemicals have ever been investigated by carcinogenicity assay in experimental animals ${ }^{18-28}$. Our study suggested that it might have a potential for detecting chemicals inducing astrocytomas which cannot be detected by other screening tests. Other anticancer drugs, mutagens and carcinogens should be estimated in order to confirm our method.

This experiment is the first step to develop and estimate our screening test of chemicals using new born rat primary cultured astrocytes, and might be applicable to detect new chemicals inducing astrocytomas, and to detect structural chromosomal aberrations, and DNA damages etc. Further study is needed.

\section{Acknowledgements}

The authors thank Professor Hidesuke Shimizu of the Jikei University School of Medicine for his valuable assistance and advice.

\section{References}

1) Tennant RW, Margolin BH, Shelby MD, Zeiger E, Haseman JK, Spalding J, Caspary W, Resnick M, Stasiewicz S, Anderson B, Minor R (1987) Prediction of chemical carcinogenecity in rodents from in vitro genetic toxicity assays. Science 236, 933-41.

2) Shirasu $Y$, Moriya M, Kato K, Lienard F, Tezuka H, Teramoto S, Kada T (1977) Mutagenicity screening on pesticides and modification products: $A$ basis of carcinogenicity evaluation. In: Origins of Human Cancer Book A. eds. by Hiatt HH, Watson JD, Winsten JA, 267-85, Cold Spring Harbor Laboratory, University of Tokyo Press.

3) OECD (1986) Guideline for Testing of Chemicals, Genetic Toxicology (\#471-485).

4) Thomas TL (1994) Primary brain tumors associated with chemical exposure. In: Occupational neurology and clinical neurotoxicology. eds. by Bleeker ML, 187206, Williams and Wilkins, Baltimore, USA.

5) Li J, Suzuki Y, Shimizu H, Fukumoto M, Okonogi H, Nagashima T, Ishikawa T (1993) In vitro micronucleus assay of 30 chemicals in CHL cells. Jikeikai Med J 40,
69-83.

6) Suzuki Y, Shimizu H, Kim SU (1997) Induction of micronucleus in NSC19 motoneuron cell line by genotoxic chemicals. Neuro Toxicology 18, 325-30.

7) Schoenberh BS (1982) Nervous system. In: Cancer epidemiology and prevention. eds. by Schottenfeld D, Fraumeni JF, 968-83, W. B. Saunders, Philadelphia.

8) Heddle LA, Hite M, Kierkhart B, Mavourin K, MacGregor JT, Newell GW, Salamone MF (1983) The induction of micronuclei as a measure of genotoxicity, A report of the US Environmental Protection Agency Gene-Tox Program. Mutation Res 123, 61-118.

9) McCarthy KD, Vellis JD (1980) Preparation of separate astroglial and oligodendroglial cell cultures from rat cerebral tissue. J Cell Biology 85, 890-902.

10) Matsushima $T$, Sawamura $M$, Hara $K$, Sugimura $T$ (1976) A safe substitute for polychlorinated biphenyls as an inducer of metabolic activation system. In: In vitro metabolic activation in mutagenesis testing. eds. by de Serres FJ, Fouts JR, Bend JR, Philpot RM, 8588, North-Holland Biomedical Press, Amsterdam.

11) Kastenbaum MA, Bowman KO (1970) Tables for determining the statistical significance of mutation frequencies. Mutation Res 9, 527-49.

12) Countryman PI, Heddle JA (1976) The production of micronuclei from chromosome aberrations irradiated cultures of human lymphocytes. Mutation Res 41, 32132.

13) Maekawa A, Mitsumori K (1990) Spontaneous occurrence and chemical induction of neurogenic tumors in rats-influence of host factors and specificity of chemical structure. Crit Rev Toxicol 20, 287-310.

14) Anderson D, Bishop JB, Garner RC, Ostrosky-Wegman P, Selby PB (1995) Cyclophosphamide: Review of its mutagenicity for an assessment of potential germ cell risks. Mutation Res 330, 115-81.

15) Ohara $H$, Terasima $T$ (1972) Lethal effect of mitomycinC on cultured mammalian cells. Jpn J Cancer Res 63, 317-27.

16) Himes RH, Kersey RN, Heller-Bettinger I, Samson FE (1976) Action of the vinca alkaloids vincristine, vinblastine, and desacetylvinblastine amide on microtubules in vitro. Cancer Res 36, 3798-802.

17) Hayashi M, Sofuni T, Ishidate Jr. M (1984) Kinetics of micronucleus formation in relation to chromosomal aberrations in mouse bone marrow. Mutation Res 127, 129-37.

18) Raju NR, Yaeger MJ, Okazaki DL, Lovell K, Koestner 
A (1990) Immunohistochemical characterization of rat central and peripheral nerve tumors induced by ethylnitrosourea. Toxicol Pathol 18, 18-23.

19) Ishida $Y$, Tamura $M$, Kanda $H$, Okamoto $K$ (1975) Histopathological studies of the nervous system tumors in rats induced by N-nitroso-methyl-urea. Acta Path Jap 25, 385-401.

20) Jinnai H (1978) Studies of N, N'-dimethylnitrosoureainduced brain tumors in rats-especially, on microtumors. Acta Med Okayama 32, 119-37.

21) Lijinsky W, Reuber MD, Blackwell BN (1980) Carcinogenecity of nitrosotrialkylurea in Fisher 344 rats. JNCI 65, 451-3.

22) Maekawa $A$, Odashima $S$ (1975) Induction of tumors of the nervous system in the ACI/N rat with 1-butyl-1nitorourea administered transplacentally, neonatally, or via material milk. Jpn J Cancer Res 66, 175-83.

23) Hecht SS, Lijinsky W, Kovatch RM, Chung F-L, Saavedra JE (1989) Comparative tumorigenicity of $N$ nitroso-2-hydroxymorpholine, $N$-nitrosodiethanolamine and $N$-nitrosomorpholine in $\mathrm{A} / \mathrm{J}$ mice and $\mathrm{F} 344$ rats.
Carcinogenesis. 10, 1475-7.

24) Spatz M, Laqueur GT (1967) Transplacental induction of tumors in Sprague-Dawley rats with crude cycad material. Natl Cancer Inst 38, 233-45.

25) Imhof $W$, Ivankovie $S$ (1983) Carcinogenic activity of 1-Phenyl- and 1-(Pyridyl-3)-3,3-dimethyl-triazene and of 1-Phenyl- and 1- (Pyridyl-3)-3,3-diethyl-triazen by single pre- and postnatal application to BD IX rats. Arch Geschwurlstforsch 53, 557-69 (German).

26) Rice JM, Ward JM (1982) Age dependence of susceptibility to carcinogenesis in the nervous system. Ann NY Acad Sci 381, 274-89.

27) Swann PF, Magee PN (1969) Induction of rat kidney tumours by ethyl methanesulphonate and nervous tissue tumours by methyl methanesulphonate and ethyl methanesulphonate. Nature 223, 947-9.

28) Weisburger EK, Ulland BM, Nam J, Gart JJ, Weisburger JH (1981) Carcinogenecity tests of certain environmental and industrial chemicals. JNCI 67, 7588. 